\title{
Evaluating Toxicological Properties of Claydite Gravel, Containing Ferrovanadium Production Sludge, by Method of Biotesting with the of Higher Plants
}

\author{
Irina Starostina ${ }^{1, *}$, Tatyana Vasilenko $^{1}$, Michael Simonov ${ }^{1}$ and Eugene Pendurin ${ }^{1}$ \\ ${ }^{1}$ Belgorod State Technological University n.a. V.G. Shukhov, Belgorod, 308012, Russia
}

\begin{abstract}
Recycling of sludge wastes, generated at industrial wastewater treatment and containing heavy metals, is a relevant and long-term task in building materials production. At that, the possibility of toxicants emission to the environment should be taken into account. This paper presents the findings of evaluating toxicological properties of artificial porous aggregates (claydite gravel), containing ferrovanadium production sludge, by means of using higher plants (Avena Sativa and Allium cepa) as test objects. It is demonstrated that adding sludge to the raw charge in amount up to $15 \%$ in the process of baking intensifies the melt formation with clay minerals, which contributes to the safe binding of heavy metals, reducing their diffusion to water media. Water extracts of the obtained claydite have no phytotoxic effect on higher plants.
\end{abstract}

\section{Introduction}

Over $800 \mathrm{mln}$ tons of sludge materials of various compositions and properties, including metallurgical production sludges, are generated in Russia every year, and are virtually not recycled, but accumulated at dumping places. This is accompanied with their adverse effect on the natural environment due to the migration of toxicants to the soil and water bodies. Developing the efficient methods of sludge materials recycling with obtaining environmentally-friendly products is a relevant task nowadays.

There are various known methods of using metallurgical production sludge waste as second-hand materials or corrective additives. Such is the technology of selected reduction of metals in form of hydroxides for their subsequent usage in producing loading pigments for paint-and-lacquer materials and nickel-containing accumulators [1]. The heavy-metalscontaining metallurgical sludges are also used as a fertilizer for growing certain crops, for example, flax [2]. Of some interest is the research, aimed at using sludge formations in production of building materials - gypsum binders [3] and various ceramic products $[4,5]$.

But it must be kept in mind that waste products can pose a potential serious environmental hazard, so, their usage as raw components requires fulfilling special conditions at building materials production, i.e. homogenization of the raw mix, the safe

\footnotetext{
*Corresponding author: starostinairinav@yandex.ru
} 
binding of metals, contained in the used waste, and prevention of their seepage on the surface of the product.

The most widely used experimental method of evaluating the quality, i.e. the toxicity of building materials, produced with the use of industrial waste, is biotesting of aqueous media, obtained from these building materials, based on determining the reactions of test objects - living organisms.

At present the list of such test objects is rather extensive. It includes one-celled organisms (bacteria, yeasts, protozoa), multi-cellular organisms (fish, insects, mollusks), subcellular particles (mitochondria, chloroplasts) and biopolymers (enzymes and polyenzymatic systems) [6]. The conventional test objects for monitoring liquid media toxicity are such cladocerans as daphnia (Daphnia magna Straus), which are among the most sensitive test organisms and are considered the base biotesting object $[6,7]$. The other used organisms are rotifers (Brachionus calyciflorus), algae (Chlorella vulgaris Beijer, Scenedesmus guadricauda), infusoria (Infusorium Paramecium caudatum, Ciliata, Suctoria), higher plants - Elodea canadensis Rich, Allium cepa, Avena Sativa, duckweed Lemna minor L. and others, as well as the seeds of indicator plants [6-9].

The purpose of this research is evaluating the toxicity characteristics of artificial porous aggregates - claydite gravel, obtained with using ferrovanadium production sludges, containing heavy metals, in the raw charge. To achieve this purpose the following tasks were solved:

- to evaluate the phytotoxic effect on the environment of the sludge-containing claydite gravel samples by using higher plants - Avena Sativa and Allium cepa.

\section{Materials and methods}

The earlier studies have demonstrated the good perspectives of using ferrovanadium production wastewater treatment sludges - iron-containing concentrate (ICC) and limestone-plaster composition (LPC) in technology of producing artificial porous aggregates - claydite gravel [10]. The ICC and LPC sludges are highly-watered finelydispersed amorphocrystalline polymineral formations [11], containing iron compounds, gypsum, $\mathrm{CaCO}_{3}$, sulphated form of hydrated calcium sulfoferrite $\left(2 \mathrm{CaO} \cdot \mathrm{Fe}_{2} \mathrm{O}_{3} \cdot 3 \mathrm{CaSO}_{4} \cdot 32 \mathrm{H}_{2} \mathrm{O}\right), \mathrm{Ca}(\mathrm{OH})_{2}$, as well as heavy metals - manganese, zinc, chrome (Tab. 1, 2).

Among the iron-containing components the oxides $-\mathrm{Fe}_{2} \mathrm{O}_{3}$ and $\mathrm{FeO}-$ should be singled out. The iron oxide in the form of hematite $\left(\mathrm{Fe}_{2} \mathrm{O}_{3}\right)$, being a highly-reactive substance, when mixed with the clayish component, forms low-melting eutectic mixtures, stimulates the intensive formation of ferrous silicate melts and glass, initiates mullite formation and intensifies sintering processes [10].

Table 1. Chemical composition of slurry material, weight $\%$

\begin{tabular}{|c|c|c|c|c|c|c|c|c|}
\hline Sludge & $\mathbf{C a O}$ & $\mathbf{M g O}$ & $\mathbf{M n O}$ & $\mathbf{V}_{\mathbf{2}} \mathbf{O}_{\mathbf{5}}$ & $\mathbf{A l}_{\mathbf{2}} \mathbf{O}_{\mathbf{3}}$ & $\mathbf{F e}_{2} \mathbf{O}_{\mathbf{3}}$ & $\mathbf{T i O}_{\mathbf{2}}$ & $\mathbf{S i O}_{\mathbf{2}}$ \\
\hline LPC & 37.3 & 4.14 & 17.8 & 3.7 & 0.32 & 0.74 & - & 2.29 \\
\hline ICC & 16.87 & 0.91 & 4.48 & 2.77 & 2.27 & 32.5 & 6.9 & 11.17 \\
\hline
\end{tabular}

Table 2. Heavy metals content in the sludge material, $\mathrm{mg} / \mathrm{kg}$

\begin{tabular}{|c|c|c|c|c|c|c|c|c|}
\hline Sludge & Mn & $\mathbf{C u}$ & $\mathbf{Z n}$ & $\mathbf{C d}$ & $\mathbf{P b}$ & $\mathbf{C o}$ & $\mathbf{N i}$ & $\mathbf{C r}$ \\
\hline ICC & 4199.0 & 3.25 & 26.8 & 0.027 & 3.88 & 0.84 & 3.34 & 668.1 \\
\hline LPC & 308.8 & 6.23 & 2.54 & 0.44 & 3.04 & 2.11 & 6.42 & 6.45 \\
\hline
\end{tabular}


The sludges are characterized with high gas emission - as a result of baking sludgecontaining claydite samples, the gaseous products of iron oxides reduction $\left(\mathrm{CO}_{2}, \mathrm{CO}\right.$ and $\left.\mathrm{H}_{2} \mathrm{O}\right)$ and dissociation of sulphates and carbonate inclusions $\left(\mathrm{SO}_{2}, \mathrm{SO}_{3},\left(\mathrm{CO}_{2}\right)\right.$ are generated. So, the ICC and LPC sludges, added to the raw mix of claydite gravel, possess double properties - gas-forming and fluxing. Their usage increases the swelling number and reduces the density of claydite grains as compared to control compositions.

To evaluate phytotoxic effect the water extracts were prepared - the claydite grains under study were put into distilled water at the ratio of 1:10 and kept within 24 hours with constant stirring. After filtering the obtained liquids were used as the growing medium for germination of test objects, which were presented by higher plants - common oats, Avena Sativa, and bulb onion, Allium cepa.

The evaluation of phytotoxic effect is based on the ability of Avena Sativa seeds to react to an exogenous chemical action by alteration of root elongation intensity, which allows using the root length as test function. As an adverse effect criterion the inhibition of seeds' roots growth is taken. The phytotoxic effect is considered proven, if the effect $\left(E_{T}\right)$ amounts to $20 \%$ and more. The value of inhibition effect, $E_{T}, \%$, was determined by the formula:

$$
E_{T}=\frac{L_{c}-L_{e s}}{L_{c}} \cdot 100,
$$

where $L_{c}$ - average root length in the control sample, $\mathrm{mm} ; L_{e s}$ - average root length in the experimental sample, $\mathrm{mm}$.

The toxicity of the medium was evaluated using Allium cepa by the mitotic activity of the root apexes' meristematic tissue cells, expressed with mitotic index (MI, \%o). Mitosis is one of the most important biological processes, as it is associated with hereditary information transmission. MI was determined by the number of mitoses per one thousand of tissue cells. For calculating MI the temporary squash preparations of Allium cepa root apexes were made, fixed and stained according to the methodology [12].

The meristematic tissue of Allium cepa root apexes was studied in the morning (8-10 a.m.). At making squash preparations the methods of maceration (Latin maceratio softening) are of paramount importance. In this case it means treating preparations with the purpose of dividing them into separate cells. The fixation was performed by means of $45 \%$ acetic acid within $10-30$ minutes at $20^{\circ} \mathrm{C}$. Then the preparation was put into the hot $\left(60{ }^{\circ} \mathrm{C}\right)$ solution of $1.0 \mathrm{~N}$ hydrochloric acid for 15-30 seconds. During fixation the quick cells death takes place, the biochemical processes are stopped and the colloids of cytoplasm become insoluble. Then the preparation was stained with acetocarmine. The squash preparation of meristem was prepared in $30 \%$ acetic acid, which decolorizes the cytoplasm. MI was determined according to the formula, $(\%)$ :

$$
\mathrm{MI}=\frac{P+M+A+T}{I+P+M+A+T} \cdot 1000
$$

where $P$ - number of cells in prophase, $M$ - metaphase, $A$ - anaphase, $T$ - telophase, $I$ - interphase.

All experimental studies were performed in triplicate.

The micrographs of Allium cepa cells were made with BIOLAM-I microscope in transmitted light $(\times 2300$, lens $\times 95)$ by using a photomicrographic attachment on the $4^{\text {th }}$ day of keeping bulbs in water extracts.

\section{Results and discussion}

The findings of determining the phytotoxic activity of studied claydite gravel samples, containing ICC and LPC sludge, by using Avena Sativa are presented in Tab. 3. 
The inhibition effect over $20 \%$ is typical for the water extract of claydite gravel with LPC content of $0.5 \%$, which is conditioned by the structure of the obtained claydite grains. Adding LPC to the raw mix composition in small amounts $-0.5 \%$ somewhat intensifies gas emission and the formation of porous structure and increases the swelling number of grains up to 4.2 as compared to the control composition - 3.3.

Table 3. Calculation data of toxicity parameters and hazard assessment of the claydite samples, containing ICC and LPC sludge, using Avena Sativa seeds as test object

\begin{tabular}{|c|c|c|c|c|c|c|c|}
\hline \multirow{2}{*}{ № } & $\begin{array}{c}\text { Sludge } \\
\text { content in the } \\
\text { claydite raw } \\
\text { mix, } \\
\text { wt.\% }\end{array}$ & \multicolumn{2}{|c|}{$\begin{array}{c}\text { Root length at } \\
\text { using sludge, } \\
\text { mm }\end{array}$} & \multicolumn{2}{|c|}{$\begin{array}{c}\text { Inhibition effect at } \\
\text { using sludge, } \\
\text { \% }\end{array}$} & \multicolumn{2}{|c|}{$\begin{array}{c}\text { Phytotoxic effect at } \\
\text { using sludge * }\end{array}$} \\
\cline { 3 - 8 } & ICC & LPC & ICC & LPC & ICC & LPC \\
\hline 1 & 0.5 & 41.15 & 27.75 & -11.37 & +24.9 & - & + \\
\hline 2 & 1 & 40.0 & 47.65 & -8.25 & -28.96 & - & - \\
\hline 3 & 2 & 38.75 & 66.1 & -4.87 & -78.89 & - & - \\
\hline 4 & 3 & 55.25 & 59.65 & -49.53 & -61.43 & - & - \\
\hline 5 & 5 & 48.8 & 46.4 & -32.07 & -25.58 & - & - \\
\hline 6 & 7 & 39.7 & 51.5 & -7.44 & -39.38 & - & - \\
\hline 7 & 10 & 68.9 & 41.1 & -86.47 & -11.23 & - & - \\
\hline 8 & 15 & 49.1 & 46.4 & -32.88 & -25.58 & - & - \\
\hline 0, control & - & \multicolumn{2}{|c|}{36.95} & \multicolumn{7}{|c|}{ not above 20 } & & - \\
\hline
\end{tabular}

«+» - the analyzed medium produces phytotoxic effect on the environment;

«-»- the analyzed medium doesn't produce phytotoxic effect on the environment.

At that the external surface of grains is rimmed with a solid cover of unvitrified nonamorphized clay matter from 0.4 to $1.0 \mathrm{~mm}$ thick (red in Fig. 1), which, together with gas emission intensification, results in the increase of open porosity $(5.6 \%)$ as compared to the control composition (4.0\%).

$a$

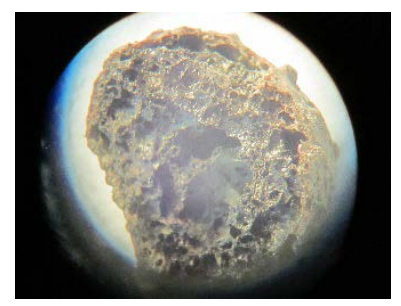

$\boldsymbol{b}$

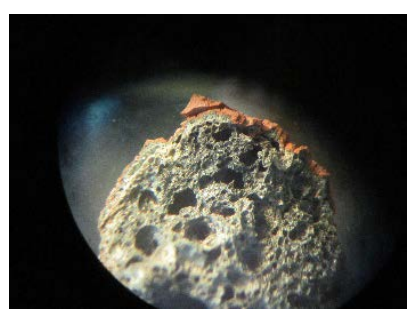

Fig. 1. The structure of claydite grains: $a$ - control composition (without sludge); $b$ - LPC content in the raw mix $0.5 \%$.

Besides, adding LPC as a ferrous admixture in amount of $0.5 \%$ doesn't provide the formation of the sufficient amount of melt, and the degree of heavy metals binding remains low. All the above-mentioned processes in aggregate contribute to the passing of heavy metals to water extracts, which causes the phytotoxic effect on Avena Sativa. The increase of LPC content in the raw mix composition up to $15 \%$ increases the melt formation and the level of heavy metals binding, and the water extracts of the obtained samples produce no phytotoxic effect on the test object (Tab.3).

Evaluation findings of the toxicity of water extracts of claydite gravel, containing ICC and LPC sludge, by using Allium cepa as a test object, are presented in Fig. 2. 


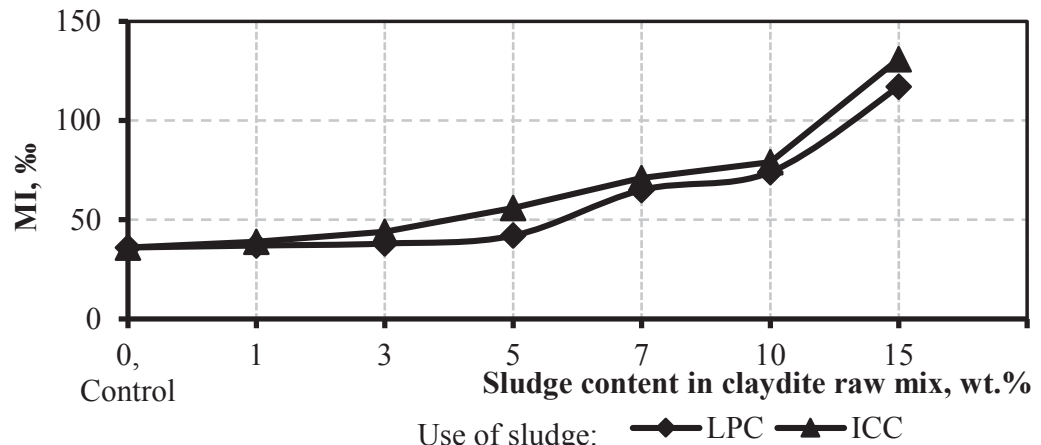

Fig. 2. The influence of sludge-containing claydite water extracts on the mitotic activity of Allium cepa root apexes meristem on the $4^{\text {th }}$ day of the experiment.

Table 4. Micrographs of Allium cepa root apexes meristem cells, exposed to water extracts of claydite gravel with various ICC and LPC sludge content

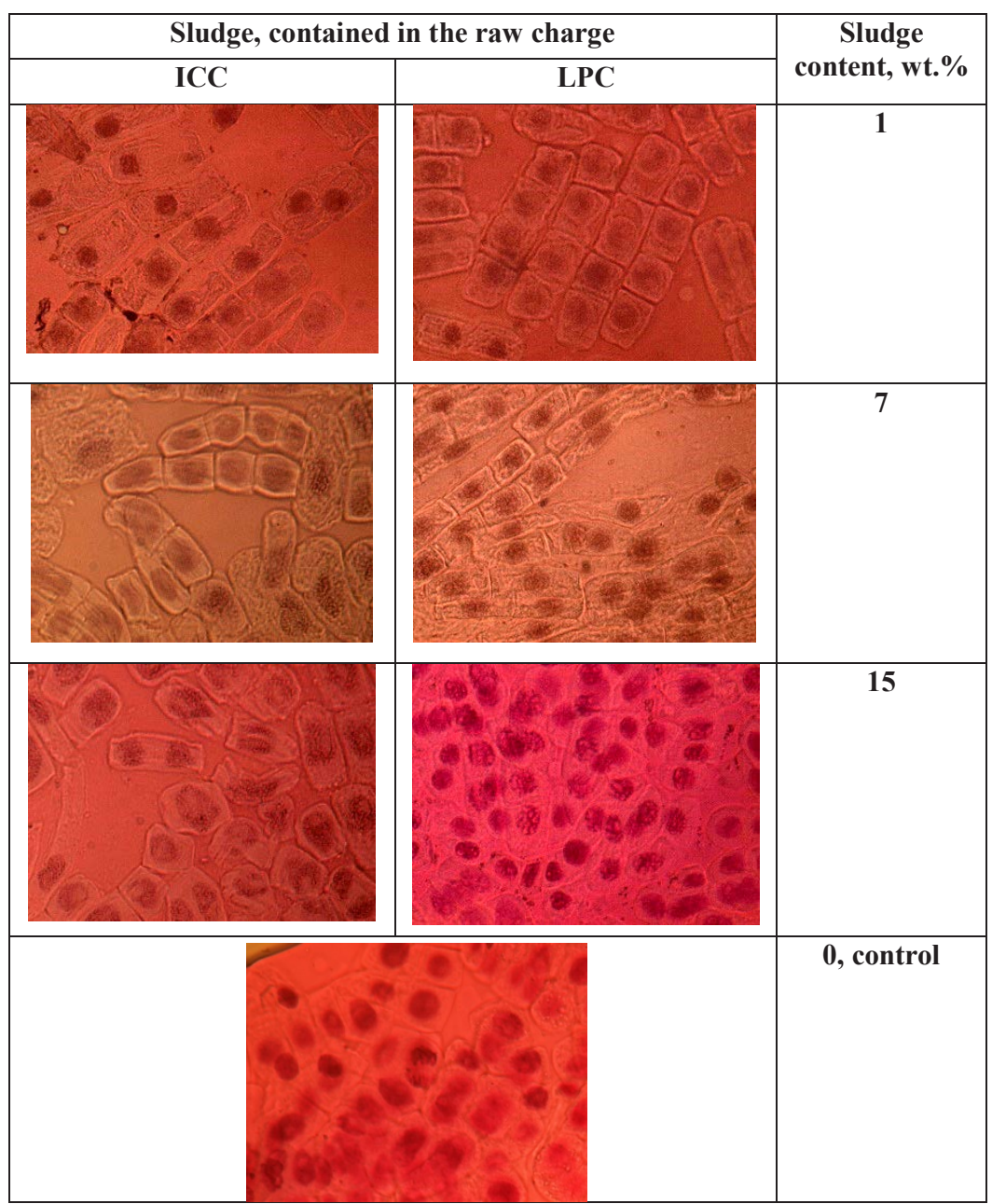

Adding LPC and ICC sludges to the claydite raw charge stimulates the Allium cepa root system development - the mitotic index value is increased. This is in good agreement with 
the microscopic studies data, presented in Tab. 4. At the content of $15 \%$ of the researched additives the MI value for ICC is by $11.96 \%$ higher and amounts to $131 \%$. Slight differences in MI values are observed at other percentage contents of LPC and ICC (5-6\%o higher for ICC at similar concentrations). This can be explained by the fact that in LPC the content of manganese compounds expressed as $\mathrm{MnO}$ is $10-25 \%$, and in ICC it is $7.0 \%$. The role of this microelement - manganese - is associated with oxidation-reduction processes regulation. Manganese takes part in ascorbic acid synthesis in plants and influences the amino acids, polypeptides and proteins synthesis [13].

It should be noted that at microscopic studies of root apexes meristems of Allium cepa, exposed to water extracts of claydite gravel with various contents of ICC and LPC sludge (Fig. 4), any atypical forms of mitosis, such as amitosis, endomitosis or polyteny [14], were not detected. Heavy metals in claydite are safely bound in chemical compounds, and their trace concentrations in the water extracts have no phytotoxic effect on higher plants, so, they pose no hazard to the environment.

\section{Summary}

According to evaluation findings of toxicological properties of the claydite gravel, containing ferrovanadium production sludge, we can make the following conclusions. Adding ferrovanadium production sludge wastes - LPC and ICC - to the claydite gravel raw charge in the process of baking intensifies melt formation with clay minerals, which contributes to the safe binding of heavy metals, contained in the sludge, reducing their diffusion to water media. The water extracts of the obtained claydite gravel samples with sludge content in amount from 1 to $15 \%$ have no phytotoxic effect on higher plants Avena Sativa and Allium cepa, used as test objects. Consequently, the heavy metals, contained in claydite gravel, pose no hazard to the environment.

The work is realized in the framework of the Program of flagship university development on the base of the Belgorod State Technological University named after V.G. Shoukhov, using equipment of High Technology Center at BSTU named after V.G. Shoukhov.

\section{References}

1. E. Lazareva, L. Olshanckaya, V. Yehorov, A. Strizhenko, Bulletin of the Kharkiv National Automobile and Highway University, 52, 83-86 (2011)

2. A. Shubina, S. Sinyutina, A. Gusev, R. Shubin, S. Abramova, Bulletin of the Tambov State Technical University, 21 (3), 470-473 (2015)

3. R. Valeyev, I. Shaykhiev, Ecology and industry of Russia, 2, 28-29 (2010)

4. T. Vasilenko, Modern problems of science and education, 5, (2013). URL: www.science-education.ru/111-10032.

5. I. Levitskiy, Yu. Pavlyukevich, E. Bogdan, O. Kichkaylo, Glass and Ceramics, 7, 7-1 (2013)

6. M. Vasilenko, E Goncharova, Biological methods of environmental quality evaluation (Belgorod, BSTU publishing office, 2017)

7. S. Bushumov, T. Korotkova, S. Ksandopulo, N. Solonnikova, V. Demin, Oriental journal of chemistry, 34 (1), 276-285 (2018)

8. V. Tsiridis, P. Samaras, A. Kungolos, G. Sakellaropoulos, Environmental Toxicology, 21, 409-416 (2006)

9. P. Firbas, T. Amon. Cytosystematics and Cytogenetics, 67 (1), 25-35 (2014) 
10. I. Starostina, M. Simonov, L. Denisova, Solid State Phenomena, 265, 501-506 (2017)

11. I. Starostina, E. Pendurin, A.Tolitchenko. Bulletin of BSTU named after V.G. Shukhov, 1, pp. 129-132 (2013)

12. O. Melekhova, E. Sarapultseva, T. Evseeva et al, Biological control of the environment: bioindication and biotesting (Publishing center «Academia», Moscow, 2007)

13. L. Donchenko, V. Nadykta, Food Safety (Pischepromizdat, Moscow, 2001)

14. V. Smirnov, Cytogenetics (Vysshaya shkola, Moscow, 1991) 